\title{
Effect of Different Protein and Energy Levels in Concentrate Diets on Nutrient Intake and Milk Yield of Saanen x Etawah Grade Goats
}

\author{
Supriyati, Krisnan R, Budiarsana IGM, Praharani L \\ Indonesian Research Institute for Animal Production, PO Box 221, Bogor 16002 \\ E-mail: skompiang@yahoo.co.id \\ (received 11-05-2016; revised 24-05-2016; accepted 21-06-2016)
}

\begin{abstract}
ABSTRAK
Supriyati, Krisnan R, Budiarsana IGM, Praharani L. 2016. Pengaruh dari perbedaan tingkatan protein dan energi pakan konsentrat terhadap asupan nutrisi dan produksi susu pada kambing Saanen x Etawah silangan. JITV 21(2): 88-95. DOI: http://dx.doi.org/10.14334/jitv.v21i2.1356

Kambing perah turut berkontribusi pada ketahanan pangan dan nutrisi. Akan tetapi, informasi terkait konsumsi nutrisi dan produksi susu (termasuk komposisinya) kambing persilangan Saanen x Etawah (SAPERA) masih terbatas. Penelitian ini bertujuan untuk mengevaluasi asupan nutrisi, produksi susu dan komposisi kandungan nutrisi kambing SAPERA yang sedang menyusui yang diberi pakan dengan tingkat energi dan protein konsentrat yang berbeda. Tiga puluh kambing SAPERA multipara dianalisis menggunakan rancangan acak kelompok dengan tiga perlakuan (R1, R2, dan R3) dan 10 pengulangan selama 12 minggu laktasi. Pakan konsentrat yang diformulasikan mengandung 18\% PK dan 72\% TDN (R1), 17\% PK dan 75\% TDN (R2), dan 16\% PK dan 78\% TDN (R3). Domba betina dipelihara dalam kandang individu dan diberikan pakan basal (cacahan rumput raja segar secara ad libitum sebanyak $500 \mathrm{~g}$ dari campuran pakan hijauan) dan $1 \mathrm{~kg}$ konsentrat perlakuan. Hasil penelitian menunjukkan bahwa perlakuan $(\mathrm{R} 1, \mathrm{R} 2$, dan $\mathrm{R} 3)$ memiliki pengaruh nyata $(\mathrm{P}<0.05)$ terhadap asupan $\mathrm{PK}, \mathrm{PT}, \mathrm{Ca}, \mathrm{P}$ dan FCR tetapi tidak berpengaruh nyata $(\mathrm{P}>0.05)$ terhadap asupan BK dan TDN. Perbedaan yang tidak nyata ditemukan pada produksi dan komposisi susu antar perlakuan. Berdasarkan hasil penelitian, dapat disimpulkan bahwa pakan terbaik untuk kambing SAPERA menyusui adalah campuran dari rumput cacah, campuram hijauan dan konsentrat (16\% PK dan 78\% TDN) dengan $160 \mathrm{~g} / \mathrm{kg}$ PK dan $750 \mathrm{~g} / \mathrm{kg}$ TDN dari total BK yang memproduksi susu sebanyak $1.55 \mathrm{~kg} / \mathrm{hari}$ dengan kandungan 90 $\mathrm{g} /$ hari lemak, $43 \mathrm{~g} / \mathrm{hari}$ protein dan $75 \mathrm{~g} / \mathrm{hari}$ laktosa.
\end{abstract}

Kata Kunci: Energi, Protein, Kambing Persilangan Saanen X Etawah, Laktasi, Produksi Susu

\section{ABSTRACT}

Supriyati, Krisnan R, Budiarsana IGM, Praharani L. 2016. Effect of different protein and energy levels in concentrate diets on nutrient intake and milk yield of Saanen $x$ Etawah Grade goats. JITV 21(2): 88-95. DOI: http://dx.doi.org/10.14334/jitv.v21i2.1356

Dairy goat contributes to food and nutrition security. However, information on nutrient consumption and milk yield, as well as milk composition of Saanen $x$ Etawah (SAPERA) grade goat is limited. This experiment was done to evaluated nutrient intake, milk yield and its composition of lactating SAPERA goats fed with different levels of dietary energy and protein in concentrate diet. Thirty multiparous SAPERA goats were used in a randomized block design with three treatments (R1, R2 and R3) and ten replications for 12 weeks of lactation. The concentrate diets were formulated to contain: $18 \%$ CP and $72 \%$ TDN (R1), $17 \% \mathrm{CP}$ and $75 \% \mathrm{TDN}$ (R2), 16\% CP and 78\% TDN (R3). Those does were penned individually, and fed by basal diet (fresh chopped King Grass ad libitum, $500 \mathrm{~g}$ of fresh mixed forages) and $1 \mathrm{~kg}$ of experimental concentrate. Results showed that the treatments had significant $(\mathrm{P}<0.05)$ effects on $\mathrm{CP}$, DIP, Ca, P intakes and FCR but had no significant $(\mathrm{P}>0.05)$ effects on DM and TDN intake. No significant differences were found in milk yield and milk composition between treatments. In conclusion, this trial suggested that the best feed for lactating SAPERA goats was the mixture of chopped grasses, mixed forages and concentrate diets (16\% CP and 78\% TDN) with $160 \mathrm{~g} / \mathrm{kg} \mathrm{CP}$ and $750 \mathrm{~g} / \mathrm{kg}$ TDN of the total DM, produced a milk of $1.55 \mathrm{~kg} / \mathrm{d}$ with $90 \mathrm{~g} /$ day of milk fat, $43 \mathrm{~g} /$ day of milk protein and $75 \mathrm{~g} /$ day of milk lactose.

Key Words: Energy, Protein, Saanen X Etawah Grade Goat, Lactation, Milk Yield

\section{INTRODUCTION}

Population of goat in Indonesia was around 18.88 million heads in 2015 (DGLAH 2015) used for milk and meat production. This Saanen breed was introduced in to breeding program of the Indonesian Research
Institute for Animal Production to improve quality and quantity of goat milk yield. This Saanen breed often produced triplets (Mellado et al. 2011) and higher milk yield compared to Etawah Grade (Praharani 2014) and Angora goats (Anwar et al. 2015). Therefore, Saanen genetics were used to produce a new goat breed with 
higher milk yield and adapted well to Indonesian environmental conditions. Saanen goats were crossed with Etawah goats to produce crossbred Saanen and Etawah grade goats, named as SAPERA.

Information on feed intake and nutrient utilization of these SAPERA goats under traditional or intensive production systems are infrequent in Indonesia. Goat feeding involves combining various feedstuffs into an acceptable and palatable ration to meet nutrient requirements. These requirements vary depending on the stage of growth, gestation and lactation. The considered nutrients in diet formulation are energy, protein, minerals, vitamins and water. The balance of nutrients will determine performance of a dairy goat. Lactating doe requires high level of energy, protein, and water for milk yield. Basal diets of dairy goats were often supplemented with concentrate to meet their requirements.

Nutritional requirements of energy and protein of goats have been reported and reviewed by some previous researchers. Krishnamoorthy \& Moran (2011) reviewed that the nutritional requirement of goats in the tropic could refer to as recommended by the Nutrient Requirement Council (NRC). Energy required by female Etawah grade goat was 1.1 times NRC (Supriyati et al. 2014a) and for female Anglo Nubian goat was 1.2 times NRC (Supriyati et al. 2014b). Martínez-Marín et al. (2011) reported that intake of metabolism energy (ME) was $5.4 \%$ greater than that recommended by the NRC for young female MurcianoGranadina dairy goats. Park et al. (2010) suggested that minimum dietary level of protein and energy was $15 \%$ $\mathrm{CP}$ and $60 \%$ TDN in mid lactation for Saanen dairy goats.

This study was aimed to evaluate effect of different level protein and energy in concentrate diets on nutrient intake, milk yield and milk composition of SAPERA goats during the first 12 weeks lactation.

\section{MATERIALS AND METHODS}

\section{Animal and feeding trial}

Thirty multiparous of SAPERA goats, around 3-4 years with an average body weight of $40.75 \pm 3.35 \mathrm{~kg}$, were used in this trial. Animals were grouped into three concentrate diets treatments. Those concentrate diets were formulated at different crude protein (CP) and total digestible nutrients (TDN) levels, i.e. $\mathrm{R} 1=18 \% \mathrm{CP}$ and $72 \% \mathrm{TDN}, \mathrm{R} 2=17 \% \mathrm{CP}$ and $75 \% \mathrm{TDN}$ and $\mathrm{R} 3=$ $16 \% \mathrm{CP}$ and $78 \% \mathrm{TDN}$ on dry matter (DM) basis. Animals were offered chopped fresh King grass ad libitum, $500 \mathrm{~g}$ of fresh mixed forages and $1 \mathrm{~kg}$ of concentrate diet as feed during the first 12 weeks of the lactation period. Table 1 shows the chemical composition of feed. The experimental design applied was completely randomized in three treatments and ten replications. Each animal was housed in individual cage. Those cages had metal wire galvanized floors and attached to each cage was a secured woody container for feed. Water was provided through a nipple in each cage. Feed intakes were measured daily.

Parameters observed were nutrient intake of DM, $\mathrm{CP}$, digestible intake protein (DIP), TDN, neutral detergent fiber (NDF), acid detergent fiber (ADF), calcium $(\mathrm{Ca})$ and phosphorus (P). DM, CP, NDF, ADF, $\mathrm{Ca}$ and $\mathrm{P}$ contents of the grass, mixed forage and concentrate diets were analyzed according to the AOAC method (AOAC 2012) modified in ours laboratory. Gross energy values were determined by bomb calorimeter (Adiabatic Bomb, Parr Instrument Co), and these values were used for TDN calculation as described by NRC (1981). Percentage of total digestible of nutrient $(\mathrm{TDN})=\mathrm{Kcal} / \mathrm{kg}$ metabolism of energy (ME) divided by 0.0361 , where $\mathrm{ME}$ is equal with 0.62 $\mathrm{Kcal} / \mathrm{kg}$ of Gross Energy (NRC 1981) and 0.0361 is the conversion factor of $\mathrm{ME}$ to $\mathrm{TDN}$ as described by Langston University's ME calculator.

Table 1 Chemical composition of feed on DM basic

\begin{tabular}{|c|c|c|c|c|c|}
\hline \multirow[b]{2}{*}{ Variables $(\%)$} & \multirow[b]{2}{*}{ Grass } & \multirow[b]{2}{*}{ Mixed forages } & \multicolumn{3}{|c|}{ Concentrate diets } \\
\hline & & & $\begin{array}{c}\mathrm{R} 1 \\
18 \% \mathrm{CP}, 72 \% \mathrm{TDN}\end{array}$ & $\begin{array}{c}\mathrm{R} 2 \\
(17 \% \mathrm{CP}, 75 \% \mathrm{TDN}\end{array}$ & $\begin{array}{c}\mathrm{R} 3 \\
(16 \% \mathrm{CP}, 78 \% \mathrm{TDN})\end{array}$ \\
\hline Crude protein & 9.09 & 20.56 & 18.23 & 17.32 & 16.32 \\
\hline Total digestible nutrient & 67.20 & 74.44 & 72.13 & 74.96 & 77.48 \\
\hline Neutral detergent fiber & 63.65 & 56.24 & 41.32 & 39.56 & 38.66 \\
\hline Acid detergent fiber & 48.27 & 50.71 & 21.40 & 22.37 & 21.58 \\
\hline Calcium & 0.34 & 1.39 & 1.02 & 1.19 & 1.13 \\
\hline Phosphorus & 0.29 & 0.16 & 0.94 & 0.96 & 0.88 \\
\hline
\end{tabular}


At the end of the experiment, digestible intake protein (DIP) was measured using total collection technique in metabolism cages. Four animals of each treatment from similar experimental goats were pleaced in individual metabolism cages. These animals were allowed ten days to adjust to the feed, followed by seven days collection. Feed intake, refusals and fecal output were recorded and kept, and a sub sample of each ( $10 \%$ of daily output in case of feces) was retained for analysis. Samples were then dried, grounded, and analyzed for protein.

Digestibility of protein intake (DIP) was calculated as follows:

DIP $(\%)=\frac{\text { Protein intake }- \text { Protein in feces }}{\text { Protein intake }} \times 100$

\section{Milk yield and samples}

Goats were milked by hand in the morning and evening. Individual morning and evening milk yields were recorded daily for each goat. The $4 \%$ fat corrected milk (FCM) for each goat was calculated from milk yield and percentage of milk fat using the formula as given by Gaines 1928) i.e. $4 \% \mathrm{FCM}=(0.4 \mathrm{x} \mathrm{g}$ milk yield $)+(0.15 \times$ g milk yield $x \%$ fat $)$. FCR value during lactation was determined as the amount of DM intake required to produce $1 \mathrm{~kg} 4 \% \mathrm{FCM}$ yield.

Milk samples from the consecutive evening and morning milkings were collected from each goat on day seven of each at the first week of lactation.
Approximately $30 \mathrm{ml}$ of milk from each goat were composited and stored at $+4^{\circ} \mathrm{C}$ until subsequent analysis for milk composition. Milk compositions of fat, protein, lactose, solids non-fat (SNF), total solids (TS) and specific gravity were analyzed using a LactoScan Milk Analyzer.

\section{Statistical analysis}

Data of feed intake, milk yield and milk quality of goats were subjected for analysis of variance using General Linear Model (GLM) procedure of SAS (SAS 2002). If there was a significant difference between treatments, the difference then was compared using Duncan's Multiple Range Test at a significance level of $\mathrm{P}<0.05$.

\section{RESULTS AND DISCUSSION}

\section{Nutrient intake}

Table 2 shows feed (grass, concentrate, forages, and total DM), CP, TDN, NDF, ADF, $\mathrm{Ca}$ and $\mathrm{P}$ intakes during lactation. The feed (grass, concentrate, mixed forages and total DM) intakes were not significantly different $(\mathrm{P}>0.05)$ among the treatments. However, there was a significant difference in $\mathrm{CP}$, DIP, $\mathrm{Ca}$ and $\mathrm{P}$ intakes between treatments $(\mathrm{P}<0.05)$ but no effect on TDN, NDF, ADF and ratio of roughage to concentrate intakes during lactation period.

Table 2. Average daily nutrient intake of goats fed different levels of protein and energy during lactation

\begin{tabular}{lccccc}
\hline \hline & \multicolumn{3}{c}{ Concentrate diets } & SEM & P value \\
\cline { 2 - 4 } Parameter $(\mathrm{g})$ & $\mathrm{R} 1$ & $\mathrm{R} 2$ & $\mathrm{R} 3$ & \\
\hline Grass & $(18 \% \mathrm{CP}, 72 \% \mathrm{TDN})$ & $(17 \% \mathrm{CP}, 75 \% \mathrm{TDN})$ & $(16 \% \mathrm{CP}, 78 \% \mathrm{TDN})$ & \\
Concentrate & 420 & 444 & 433 & 37.89 & 0.340 \\
Forage & 824 & 845 & 768 & 11.04 & 0.316 \\
Total dry matter & 153 & 153 & 153 & - & - \\
Ratio roughage to concentrate & 1377 & 1442 & 1354 & 110 & 0.177 \\
Crude protein & 0.71 & 0.71 & 0.79 & 0.12 & 0.290 \\
Digestible intake protein & $236^{\mathrm{a}}$ & $237^{\mathrm{a}}$ & $216^{\mathrm{b}}$ & 19.56 & 0.052 \\
Total digestible nutrient & $174^{\mathrm{a}}$ & $172^{\mathrm{a}}$ & $157^{\mathrm{b}}$ & 14.38 & 0.040 \\
Neutral detergent fiber & 982 & 1043 & 1011 & 84.26 & 0.304 \\
Acid detergent fiber & 713 & 725 & 686 & 46.51 & 0.211 \\
Calcium & 452 & 477 & 452 & 27.20 & 0.096 \\
Phosphorous & $11.75^{\mathrm{b}}$ & $13.59^{\mathrm{a}}$ & $12.26^{\mathrm{b}}$ & 1.25 & $<0.0001$ \\
\hline
\end{tabular}

abc Values in the same row having different letters show significant $(\mathrm{P}<0.05)$ difference 
Average total daily DM and TDN intakes were not significant $(\mathrm{P}>0.05)$ among those three treatments during the first 12 weeks lactation. In this trial, the does were separated with the kids, therefore, nutrient requirement of goats during lactation considered similar to the values recommended by (NRC 2007) for single kid. Furthermore, results of this trial showed that average litter size of goats was 1.4 (data was not shown in the Table). The mean daily total DM and TDN intakes in this trial were less (0.84 times) and similar (0.98 times) to the NRC requirement. According to NRC (2007), daily requirement of DM and TDN for early lactation of a single kid dairy goat at $40 \mathrm{~kg}$ of BW and $-21 \mathrm{~g}$ ADG was $1.67 \mathrm{~kg}$ and $1.03 \mathrm{~kg}$, respectively. Kearl (1982) recommended requirement of DM and TDN intakes for the first 10 weeks of lactating goats at $40 \mathrm{~kg}$ of BW were 1.90 and $1.05 \mathrm{~kg}$, respectively. From the above results, only the TDN requirement of lactation goats in this trial was closed to Kearl's and NRC's recommendations.

In this trial, different level of protein and energy did not affect DM intake during lactation period. A similar result was reported by Goetsch et al. (2001) that increase energy level had no effect on DM intake of lactating Alpine dairy goats. However, our findings were in contrary from those reported by Rufino et al. (2012), that supplementation of concentrate as sources of protein and energy up to $1.5 \% \mathrm{BW}$ under grasspasture increased DM and nutrients intake of goats. Furthermore, Teh et al. (1994) reported that high yielding goats required great amounts of energy during early lactation.

Moreover, different levels of protein and energy in the concentrate diets significantly influenced $(\mathrm{P}<0.05)$ the mean daily $\mathrm{CP}$ intakes of feed during the lactation period (Table 2). CP intake was higher than Kearl's recommendation Kearl (1982) and NRC requirement (NRC 2007). Requirement of total protein for lactating goats at $40 \mathrm{~kg}$ of BW and $-20 \mathrm{~g}$ ADG were $160 \mathrm{~g}$ (Kearl 1982) and 89 g UIP $40 \%$ and $80 \mathrm{~g}$ DIP (NRC 2007) for single kid, respectively. Intakes of $\mathrm{Ca}$ and $\mathrm{P}$ in this trial were higher than Kearl's recommendation (Kearl 1982) and NRC requirements (NRC 2007). Requirement of Ca and $\mathrm{P}$ for lactating goats at $40 \mathrm{~kg}$ of $\mathrm{BW}$ and $-20 \mathrm{~g}$ ADG were $5 \mathrm{~g}$ and $3.5 \mathrm{~g}$ (Kearl 1982), and $5.9 \mathrm{~g}$ and $3.9 \mathrm{~g}$ for single kid (NRC 2007), respectively.

The main daily intakes of NDF and ADF in this trial were not significant $(\mathrm{P}>0.05)$ but the main daily intake of ADF were significantly $(\mathrm{P}<0.05)$ different among those concentrate diets. NDF percentages in total DM intakes were $51.78,50.23$, and $50.66 \%$ for R1, R2, and R3, respectively. Meanwhile, ADF contents were 32.82, 33.07 , and $33.38 \%$ for R1, R2, and R3, respectively. $\mathrm{NDF}$ and ADF contents of feed intakes were higher than NRC recommendation. The 18 to $20 \%$ ADF or $41 \%$ NDF was nutritionally adequate for high producing lactating dairy goats (Lu et al. 2008; MirzaeiAghsaghali \& Maheri-Sis 2011). Moreover, the ratio of roughage to concentrate intakes in this trial was in range as recommended, except for R3 diets which was slightly higher than their recommendations (40:60\%). Minimum recommended dairy NDF and ADF were 25 to $28 \%$ and 19 to $21 \%$, respectively, with at least $75 \%$ of this NDF from forages rather than concentrate. Lower dietary fiber level could depress milk fat percentage and increase fat storage in the body of the doe during lactation.

In this trial, different levels of protein and energy in the concentrate diets had no influence $(\mathrm{P}>0.05)$ to the ratio of roughage to concentrate intakes during lactation. Intake of concentrates was in the range of 58$61 \%$ of total DM intake. These ratios of roughage to concentrate intakes were in the normal range of the feed intakes, except for the R3 diets which was slightly higher than recommended. Those concentrate diets should make up 50-60\% of the diets.

From the above results, average TDN intake was adequate to meet the requirement (Kearl 1982; NRC 2007). CP, DIP, NDF, ADF, Ca, and $P$ intakes were higher than the nutrient requirement of lactation goats as recommended by International Feeding System (Kearl 1982; NRC 2007).

\section{Milk yield}

Table 3 summarizes effect of different levels of protein and energy in concentrate diets on average daily milk yield at different weeks of lactation, 4\% FCM yields, total milk yields for 12 weeks production, FCR, milk constituents and milk composition yields. During milk yield period, different level of protein and energy in concentrate diets, where the three treatments containing $17.14 \% \mathrm{CP}$ and $71.31 \% \mathrm{TDN}$ (R1), $16.44 \%$ $\mathrm{CP}$ and $72.33 \% \mathrm{TDN}$ (R2), $15.95 \% \mathrm{CP}$ and $74.67 \%$ TDN (R3) of total feeds, did not affect $(\mathrm{P}>0.05)$ the average weekly milk yields and the total 12 weeks milk yields.

These results were similar to the result of previous researchers (Bava et al. 2001; Goetsch et al. 2001; Zambom et al. 2012) showing that milk yield was not affected by different level of protein and energy intakes. Bava et al. (2001) reported that milk yield was similar for silage-based control diet and non-forage diet (high CP content) of dairy goats. Goetsch et al. (2001) reported that milk yield in the first 12 weeks of subsequent lactation were not affected by dietary treatment of different level of energy and concentrate or parity of Alpine dairy goats. Zambom et al. (2012) evaluated milk yield of Saanen goats fed diets with soybean hulls replacing ground corn $(0,50$, and $100 \%$ replacement) in early lactation and the results showed that milk yield was not affected by three different 
Table 3. Milk yield, milk composition and milk constituent yields of goats fed different levels of protein and energy

\begin{tabular}{|c|c|c|c|c|c|}
\hline \multirow[b]{2}{*}{ Variables } & \multicolumn{3}{|c|}{ Concentrate diets } & \multirow[b]{2}{*}{ SEM } & \multirow[b]{2}{*}{$P$ value } \\
\hline & $\begin{array}{c}\mathrm{R} 1 \\
(18 \% \mathrm{CP}, 72 \% \mathrm{TDN})\end{array}$ & $\begin{array}{c}\mathrm{R} 2 \\
(17 \% \mathrm{CP}, 75 \% \mathrm{TDN})\end{array}$ & $\begin{array}{c}\mathrm{R} 3 \\
(16 \% \mathrm{CP}, 78 \% \mathrm{TDN})\end{array}$ & & \\
\hline \multicolumn{6}{|l|}{ Average daily milk yield } \\
\hline at $1-4$ th weeks, $\mathrm{ml} / \mathrm{d}$ & 1720 & 1560 & 1649 & 243 & 0.483 \\
\hline at $4-8$ th weeks, $\mathrm{ml} / \mathrm{d}$ & 1441 & 1294 & 1611 & 265 & 0.130 \\
\hline At $8-12^{\text {th }}$ weeks, $\mathrm{ml} / \mathrm{d}$ & 1166 & 1010 & 1245 & 227 & 0.189 \\
\hline At $1-12^{\text {th }}$ weeks, $\mathrm{ml} / \mathrm{d}$ & 1442 & 1288 & 1502 & 222 & 0.225 \\
\hline At $1-12^{\text {th }}$ weeks, $g / d$ & 1482 & 1324 & 1545 & 228 & 0.222 \\
\hline Total milk yield 12 weeks, 1 & 121 & 108 & 125 & 19 & 0.230 \\
\hline Total milk yield 12 weeks, $\mathrm{kg}$ & 125 & 111 & 130 & 19 & 0.222 \\
\hline Avg. Daily 4\% FCM yield, g/d & 595 & 531 & 620 & 92 & 0.223 \\
\hline Feed conversion ratio ${ }^{1}$ & $0.96^{\mathrm{ab}}$ & $1.13^{\mathrm{a}}$ & $0.94^{\mathrm{b}}$ & 0.16 & 0.068 \\
\hline \multicolumn{6}{|l|}{ Milk composition, $\%$} \\
\hline Fat & 5.58 & 5.82 & 6.00 & 0.42 & 0.312 \\
\hline Protein & 2.83 & 2.82 & 2.87 & 0.69 & 0.556 \\
\hline Lactose & 4.78 & 5.15 & 4.99 & 0.38 & 0.341 \\
\hline Specific gravity & 1.028 & 1.028 & 1.029 & $<0.001$ & 0.556 \\
\hline Solid non-fat & 8.70 & 8.86 & 8.47 & 0.31 & 0.180 \\
\hline Total solids ${ }^{2}$ & 14.28 & 14.69 & 14.47 & 0.52 & 0.489 \\
\hline \multicolumn{6}{|l|}{ Milk constituent yields, $g$} \\
\hline Fat & 80.71 & 75.29 & 90.33 & 13.13 & 0.147 \\
\hline Protein & 40.71 & 36.43 & 43.00 & 6.26 & 0.185 \\
\hline Lactose & 69.14 & 66.57 & 75.17 & 11.16 & 0.390 \\
\hline Solid non-fat & 126 & 114 & 128 & 19.16 & 0.413 \\
\hline Total solids ${ }^{2)}$ & 207 & 190 & 218 & 32.38 & 0.308 \\
\hline
\end{tabular}

${ }^{1}$ Feed conversion ratio $=\mathrm{DMI} / 4 \%$ FCM yield

${ }^{2}$ Total solid $=$ Fat + Solid non-fat

$4 \%$ FCM $($ fat corrected milk $)=(0.4 \times \mathrm{g}$ milk yield $)+(0.15 \times \mathrm{g}$ milk yield $\mathrm{x} \%$ fat $)$

${ }^{\text {ab }}$ Values in the same row having different letters differ significantly $(\mathrm{P}<0.05)$

diets containing of $13 \% \mathrm{CP}$ and $66.49 \% \mathrm{TDN}, 14.5 \%$ $\mathrm{CP}$ and $63.33 \% \mathrm{TDN}$ or $15 \% \mathrm{CP}$ and $57.34 \% \mathrm{TDN}$ However, the results of this trial were in contrary with those obtained by other researchers (Sahlu et al. 1995; Park et al. 2010; Souza et al. 2014; Nascimento et al. 2014), who found that the different levels of protein and energy affected the milk yield. Sahlu et al. (1995) reported that milk yield in the subsequently lactation increased quadratically in response to pre-partum $\mathrm{CP}$ and TDN concentration. Park et al. (2010) reported that milk yield in the diets of Saanen goats containing $15.19 \% \mathrm{CP}$ and $62.60 \%$ TDN was the highest among the treatments $11.90 \% \mathrm{CP}$ and $70.08 \% \mathrm{TDN}, 12.73 \%$
$\mathrm{CP}$ and $67.03 \%$ TDN, $16.60 \% \mathrm{CP}$ and $57.90 \% \mathrm{TDN}$. Souza et al. (2012) observed that increasing dietary energy level of Saanen goats using calcium salts of fatty acids changed their lactation curves, resulting in the best milk yield response with $76.18 \%$ TDN on DM diets. Nascimento et al. (2014) reported that daily milk yield of dairy goats showed linear improvement with increasing TDN content from $65 \%$ to $75 \%$ and $85 \%$. The difference in milk yield from other result of previous study might due to the variation of goat responce to the treatment diets, breed, or stages of lactation. 
Daily average milk yields of SAPERA in this trial were higher compared to milk yield of Etawah Grade goats (Supriyati et al. 2016) and lower than milk yield of Saanen goats (Gomes et al. 2014; Zambom et al. 2012). Supriyati et al. (2016) reported that average daily milk yields of Etawah Grade goat fed with diets containing $12.6 \% \mathrm{CP}$ and $70.1 \% \mathrm{TDN}$ during 12 weeks of lactation was $0.678 \mathrm{~kg} / \mathrm{d}$. However, Gomes et al. (2014) reported that average daily milk yields of Saanen goats fed with diets based on soybean meal containing $23 \%$ CP during the first 60 days of lactation was 3.29 $\mathrm{kg} / \mathrm{d}$. Furthermore, Zambom et al. (2012) reported that average daily milk yields of Saanen goats fed based on soybean hull containing $22 \% \mathrm{CP}$ and $85 \%$ TDN during the 50 days of lactation was $3.64 \mathrm{~kg} / \mathrm{d}$. From the above results, it could be concluded that milk yield of SAPERA goats was in the middle range between Etawah Grade and Saanen goats.

\section{Milk constituents and composition yields}

Table 3 summarizes milk constituent and composition yield of goats fed different levels of energy and protein. Different levels of energy and protein in concentrate diets had no influences $(\mathrm{P}>0.05)$ on milk fat, protein, lactose, specific gravity, SNF, and TS. Milk constituent yields were also not influenced $(\mathrm{P}>0.05)$ by the different levels of energy and protein in concentrate diets.

In this trial, milk samples were collected from each goat on day seven of each week of lactation. In this period, milk samples would represent milk quality during whole experiment. As reported by Zeng et al. (1997) that milk sample collection carried out when does were in one to two weeks in lactation. They also reported that daily variation concentration of milk components did not change significantly. Milk components changed depending on the stages of lactation (Zeng et al. 1997) and traits (Silva et al. 2013).

Milk fat and total solids of goats in this trial were in the range reported by Sutama (2009) for Etawah Grade goats under the tropical region, from 4.42 to $6.4 \%$, and 13.62 to $15.72 \%$, respectively. Milk protein and milk lactose of Etawah Grade goats in this trial were less than those reported by Sutama (2009). He also reported that milk protein and milk lactose of Etawah Grade goats were 3.78 to $4.52 \%$ and 5.08 to $5.62 \%$, respectively. Protein percentage were less and fat and lactose percentage were higher than those reported by Silva et al. (2013), who worked with Saanen goats; they obtained values of $3.13,3.78$ and 4.25 , respectively. Different results from previous studies might due to the differences in feeds, breed and lactation period. From the above results showed that milk content is the most variable nutrient because of the differences between breed, feeding and their interaction.
During milk yield period, different level of protein and energy in concentrate diets, where the three treatments containing $17.14 \% \mathrm{CP}$ and $71.31 \% \mathrm{TDN}$ (R1), $16.44 \% \mathrm{CP}$ and $72.33 \% \mathrm{TDN}$ (R2), $15.95 \% \mathrm{CP}$ and $74.67 \%$ TDN (R3) of the total feeds did not affect ( $\mathrm{P}>0.05)$ milk composition and milk constituent yields. However, our findings were in contrary to those obtained by other researchers (Sahlu et al. 1995; Park et al. 2010; Zambom et al. 2012). Sahlu et al. (1995) reported that milk fat percentage increased linearly in response to increased pre-partum energy. Park et al. (2010) reported that the decrease of energy and increase of protein in diets of mid lactation Saanen goats significantly reduced the content of fat milk but the yields of milk protein and lactose increased significantly. Zambom et al. (2012) reported that milk quality of Saanen goats fed diets with soybean hulls in early lactation were not affected by three different diets containing $13 \% \mathrm{CP}$ and $66.48 \% \mathrm{TDN}, 14.5 \% \mathrm{CP}$ and $62.33 \% \mathrm{TDN}$ or $15 \% \mathrm{CP}$ and $57.34 \%$ TDN. Furthermore, Park et al. (2010) suggested that minimum dietary level of protein and energy was $15 \% \mathrm{CP}$ and $60 \% \mathrm{TDN}$ in mid lactation for Saanen dairy goats for producing the best milk composition and milk yield constituents.

The different levels of protein and energy response on milk yields and milk composition yields between different research reports might be due to many factors such as forage to concentrate ratio (Tufarelli et al. 2009; Park et al. 2010), breed and traits (Ciappesoni et al. 2004). But forage to concentrate ratio in this trial might not affect milk yield and milk composition since their rations were not significantly different as shown in Table 2. As reported by Tufarelli et al. (2009), ratio $35 / 65$ forage to concentrate provided greater milk yield compared to $50 / 50$ ratio and $65 / 35$ ratios without influencing milk composition during lactation period of Jonica breed goats.

\section{CONCLUSION}

Levels of protein and energy in concentrate diets had significant effects on CP, DIP, Ca, P intakes, and FCR but not on DM, TDN, NDF, and ADF intakes during lactation. No significant differences were found in milk yield and milk composition between the different levels of protein and energy in the concentrate diets. This trial suggested that the best feed for lactating SAPERA goats was the mixture of chopped grasses, mixed forages and concentrate diets (16\% CP and $78 \%$ TDN) with $160 \mathrm{~g} / \mathrm{kg} \mathrm{CP}$ and $750 \mathrm{~g} / \mathrm{kg}$ TDN of the total $\mathrm{DM}$, produced a milk of $1.55 \mathrm{~kg} /$ day with $90 \mathrm{~g} /$ day of milk fat, $43 \mathrm{~g} /$ day of milk protein and $75 \mathrm{~g} /$ day of milk lactose. 


\section{REFERENCES}

Anwar MM, Ramadan TA, Taha TA. 2015. Serum metabolites, milk yield, and physiological responses during the first week after kidding in Anglo-Nubian, Angora, Baladi, and Damascus goats under subtropical conditions. J Anim Sci. 90:4795-4806.

[AOAC] Association of Official Analytical Chemists. 2012. Official methods of analysis. 19th ed. Maryland (USA): Association of Official Analytical Chemists International.

Bava L, Rapetti L, Crovetto GM, Tamburini A, Sandrucci A, Galassi G, Succi G. 2001. Effect of a non-forage diet on milk yield, energy and nitrogen metabolism in dairy goats throughout lactation. J Dairy Sci. 84:2450-2459.

Ciappesoni G, Prybyl J, Milerski M, Mares V. 2004. Factors affecting goat milk yield and its composition. Czechoslov J Anim Sci. 11:465-473.

[DGLAH] Directorat of General Livestock and Animal Health. 2015. Livestock and animal health of statistics, Jakarta (Indones): Directorat of General Livestock and Animal Health, Ministry of Agriculture.

Gaines WL. 1928. The energy basis of measuring milk yield in dairy cows. Illinois (USA): University of Illinois.

Goetsch AL, Detweiler G, Sahlu T, Puchala R, Dawson L. 2001. Dairy goat performance with different dietary concentrate levels in late lactation. Small Rumin Res. 41:117-125.

Gomes LC, Alcalde CR, de Lima LR, de Lima LS, de Souza R, Possamai APS. 2014. Nutritive value of diets containing inactive dry yeast for lactationg Saanen goats. R Bras Zootech. 43:36-43.

Kearl LC. 1982. Nutrient requirement of ruminants in developing countries. Logan Utah (USA): International Institute of Feedstuffs, Utah Agricultural Experiment Station, Utah University.

Krishnamoorthy U, Moran J. 2011. Rearing young ruminants on milk replacers and starter feeds. In: Makkar HPS, editor. Manual of animal production and health. 13th ed. Rome (Italy): Food Association Organization.

Lu CD, Kawas JR, Mahgoub OG. 2008. Review recent advancements in fiber digestion and utilization in goats. Trop Subtrop Agroecosys. 9:65-72.

Martínez-Marín AL, Pérez-Hernández M, Pérez-Alba LM, Carrión-Pardo D, Gómez-Castro AG. 2011. Prediction of energy requirements of Murciano-Granadina preruminant female kids using the National Research Council. S Afr J Anim Sci. 41:345-349.

Mellado M, Meza-Herrera CAF, Arévalo JR, De SantiagoMiramontes MA, Rodríguez A, Luna-Orozco JR, VelizDeras FG. 2011. Relationship between litter birth weight and litter size in five goat genotypes. Anim Prod Sci. 51:144-149.
Mirzaei-Aghsaghali A, Maheri-Sis N. 2011. Importance of "physically effective fiber" in ruminant: A review. Ann Biol Res. 2:262-270.

Nascimento TVC, Miranda MS, Barros CHSC, Souza TTS, Lopes-Júnior ES, Voltolini TV, Moraes SA, Nogueira DM, Cordeiro MF. 2014. Return of postpartum ovarian activity in dairy goats supplemented with different levels of energy. Rev Bras Saúde Prod Anim. 15:10611071.

[NRC] National Research Council. 1981. Nutrient requirement of goats. Washington DC (USA): National Academy Press.

[NRC] National Research Council. 2007. Nutrient requirements of small ruminants: Sheep, goats, cervids, and new world camelids. 7th ed. Washington DC (USA): National Academy Press.

Park JK, Kim JD, Kim JA, Yoo JS, Bae GS, Kim CH. 2010. Effects of different dietary energy and protein levels on milk yield in Saanen dairy goats in mid lactation. J Korean Grassl Sci. 30:35-42.

Praharani L. 2014. Milk yield of Anglo-Nubian, Saanen x Etawah Grade and Etawah Grade raised in the same environment. In: Subandriyo, Kusmartono, Santosa KA, Kurnianto E, Purnomoadi A, Sodiq A, Wiryawan KG, Darodjah S, Inounu I, Darmono, Priyanti A, Wynn P, Han JL, Tay-Hsu J, Idrus Z, editors. Proceedings the 16th Asian-Australasian Associations of Animal Production Societies. [Yogyakarta (Indonesia)]: Universitas Gadjah Mada. p. 1527-1530.

Rufino MOA, Alves AA, Rodrigues MM, Moura RL, Cavalcante ACR, Rogerio MCP. 2012. Goat milk yield and quality on Tanzania-grass pastures, with supplementation. Acta Sci Anim Sci. 34:417-423.

Sahlu T, Hart SP, Le-Trong T, Jia Z, Dawson L, Gipson T, Teh TH. 1995. Influence of pre-partum protein and energy concentrations for dairy goats during pregnancy and early lactation. J Dairy Sci. 78:378-387.

[SAS] Statistics Analysis System. 2002. SAS/STAT user's guide. Version 9.1. North Carolina (USA): SAS Institute Inc., Cary.

Silva FG, Brito LF, Torres RA, Riberio Junior JI, Oliviera HR, Caetano GC, Rodrigues MT. 2013. Factors that influence the test day milk yild and composition. Genet Mol Res. 12:1522-1532.

Souza de R, Alcalde CR, Oliveira CAL, Molina BSL, Macedo FAF, Gomes LC, Hygino B, Possamai APS. 2014. Lactation curves and economic results of Saanen goats fed increasing dietary energy levels obtained by addition of calcium saltas of fatty acids. R Bras Zootech. 43:73-79.

Supriyati, Praharani L, Budiarsana I-GM, Sutama I-K. 2014a. Pengaruh perbedaan level protein dan energy pada konsentrat terhadap kinerja kambing betina muda Peranakan Etawah. In: Pamungkas D, Widiawaty Y, Noor SM, Purwantari ND, Widiastuti R, Brahmantiyo B, Herawati T, Kusumaningsih A, Handiwirawan E, 
Puastuti W, editors. Prosiding Seminar Nasional Teknologi Peternakan dan Veteriner. [Bogor (Indones)]: Indonesian Center for Animal Research and Development. Hlm. 449-456.

Supriyati, Praharani L, Budiarsana IGM, Sutama I-K. 2014b. Effect of different protein and energy levels in concentrate on Anglo Nubian goat performance. In: Subandriyo, Kusmartono, Santosa KA, Kurnianto E, Purnomoadi A, Sodiq A, Wiryawan KG, Darodjah S, Inounu I, Darmono, Priyanti A, Wynn P, Han JL, TayHsu J, Idrus Z, editors. Proceeding of the 16th AAAP Animal Science Congress. [Yogyakarta (Indonesia)]: Universitas Gadjah Mada. p. 1890-1894.

Supriyati, Budiarsana I-GM, Praharani L, Krisnan R, Sutama I-K. 2016. Effect of choline chloride supplementation on milk yield and milk composition of Etawah grade goats. J Anim Sci Technol. 58:1-12.
Sutama I-K. 2009. Productive and reproductive performances of female Etawah Crossbred goats in Indonesia. Indones Bull Anim Vet Sci. 19:1-6.

Teh TH, Trung LT, Jia ZH, Gipson TA, Ogden KB, Sweeney TF. 1994. Varying amounts of rumen-inert fat for high producing goats in early lactation. J Dairy Sci. 77:253258.

Tufarelli V, Dario M, Laudadio V. 2009. Forage to concentrate ration in Jonica breed goats: Influence of lactation curve and milk composition. J Dairy Sci. 76:124-128

Zambom MA, Alcalde CR, Kazama DCS, Martins EN, Hashimoto JH, Matsushita M, Ramos CECO, Grande PA. 2012. Soybean hulls replacing ground corn in diets for early lactation Saanen goats: Intake, digestibility, milk yield and quality. R Bras Zootec. 41:1-8.

Zeng SS, Escobar EN, Popham T. 1997. Daily variations in somatic cell count, composition, and production of Alpine goat milk. Small Rumin Res. 26:253-260. 